\title{
Global Climate Change and Its Impact on Agriculture Sector in Pakistan
}

\author{
Abdul Ghafoor Awan ${ }^{1 *}$, Ghulam Yaseen ${ }^{2}$ \\ ${ }^{1}$ Dean, Faculty of Management and Social Sciences, Institute of Southern Punjab, Multan, PAKISTAN \\ ${ }^{2}$ M. Phil Scholar, Department of Economics, Institute of Southern Punjab, Multan, PAKISTAN \\ *E-mail for correspondence: drabdulghafoorawan@gmail.com
}

Received: May 19, 2017;

Accepted: Aug 09, 2017;

Published: Oct 18, 2017

Source of Support: Nil

No Conflict of Interest: Declared

\begin{abstract}
Impact of global climate change on the agriculture sector of Pakistan is estimated in Pakistan. Agriculture is considered as the backbone of Pakistan economy because more $60 \%$ population is directly involved with this profession. Due to rapid industrialization the temperature level is increasing, which is harmful for agriculture crops and also for people. The objective of this research paper is to explore the impact of the global warming at agriculture sector of Pakistan and to measure climate impact on the agriculture sector in future. Times series dataset from 1974 to 2013 is used to analyze the impact. Agriculture value added annual growth rate is used as dependent variable. Carbon oxide emission, agriculture methane emission, agriculture nitrous oxide emission, greenhouse gas emission and population density are used as explanatory variables. Auto regressive distributed lag model is used as statistical technique to analyze the dataset. The result shows that the variables have significant impact on the agriculture sector of Pakistan. Auto regressive distributed lag model presents the existence of the short run and long run relationship between the dependent and independent variables. In a policy recommendation government try to reduce the warming through control on industrialization.
\end{abstract}

Keywords: $\mathrm{CO}_{2}$, Climate change, Agriculture productivity, ARDL

\section{INTRODUCTION}

Environmental change is measure by the different kind of gasses into the air. These gasses gather in the atmosphere, which result an unnatural climate change. The movements in overall air related parameters, for instance, temperature, precipitation, soil dampness and sea level. Nonetheless, the faithful nature of the conclusion on ecological change is vague. There are no hard facts about what will be the outcome of additions in the centralization of the different gasses inside nature and no firm timescales are known. Agriculture business is one territory, which is basic to consider similarly as natural change. The cultivating part both adds to natural change, and furthermore will be affected by the evolving atmosphere.

Agricultural facilities contribute to approximately $20 \%$ of the annual increase in anthropogenic emissions of greenhouse gases. This sector contributes to global warming due to emissions of carbon dioxide $\left(\mathrm{CO}_{2}\right)$, methane $\left(\mathrm{CH}_{4}\right)$ and nitrous oxide $\left(\mathrm{N}_{2} \mathrm{O}\right)$. Greenhouse gases allow the transmission of light reaching the ground; they block the transfer of heat, trying to escape from the atmosphere, thus catching heat, as in a greenhouse. $\mathrm{CH}_{4}$ has the highest global warming potential, which is approximately 300 times greater than the $\mathrm{CO}_{2}$ potential and about 20 times greater than $\mathrm{N}_{2} \mathrm{O}$. The main sources of gases are nitrogen fertilizers, flooded rice fields, soil management, land conversion, biomass burning and livestock production and associated manure management. The share of the livestock sector is from $5 \%$ to $10 \%$ of the total contribution to global warming.

\section{Climate change and agriculture in Pakistan}

It is important for a nation to make its farming part proficient to upgrade sustenance security, personal satisfaction and to advance fast monetary development. The proof frame slightest created nations (LDCs) demonstrates that farming division represents an expansive partake in their GDP (Gross domestic product). In this manner the advancement of the economy can't be accomplished without enhancing the agriculture area. As per the Monetary review of Pakistan (2011-12) its fundamental regular asset is arable land and farming area's commitment to the Gross domestic product is 21 percent. The agriculture sector ingests 45 percent of work drive and it's partake in fares is $18 \%$. Given the part of agriculture 
area in monetary development and its affectability to change in precipitation and temperature it is vital to think about the effect of environmental transform on significant harvests into Pakistan.

There are two harvests periods in Pakistan specifically, Kharif and Rabi. Rabi products are become regularly in the months of November to April and Kharif yields are developed from May to October these two seasons make Pakistan a farming country and its execution relies on upon the atmosphere amid entire year. Environmental transform for the most part influences agribusiness from side to side transforms in precipitation and temperature.

The agriculture part in Pakistan assumes a significant part as the salary of more than 47 percent of the population is reliant on this area. This division is under danger from environmental change. It is anticipated that temperatures will increment by $3^{\circ} \mathrm{C}$ by 2040 and $5^{\circ} \mathrm{C}$ to $6^{\circ} \mathrm{C}$ before this current century's over. Because of this situation, Asia can lose 50 percent of its wheat creation (MOE, 2009). Also, farming division of Pakistan is more powerless against environmental change in light of its geological area (Janjua et al, 2011). This study discloses that because of anthropogenic exercises, temperature of earth is rising and it might have negative impact on the generation of wheat. Utilizing Vector Auto Regressive (VAR) display on the yearly information from 1960 to 2009, the study did not discover noteworthy negative effect of environmental change on wheat creation in Pakistan. Be that as it may, then again, Shakoor (2011) discovered noteworthy negative effect of temperature-ascend on farming creation furthermore found the positive effect of rain fall on agribusiness generation. Investigations depended on the wheat yield and study presumed that the negative effect of temperature is more noteworthy than the positive effect of precipitation for Pakistan. The creators additionally assessed cost of bone-dry areas due to $1 \%$ increment in temperature, which came to Rs 4180 to the net income per annum.

\section{Main Research Problem}

The research problem of our study is "Global Climatic Change and its Impact on Pakistan in Agriculture Sector"

\section{Objective of the Study}

The main objectives of this study were as under:

- To study the effects of climate change on the agriculture productivity of Pakistan.

- To find out the climate change factors that have highly impact on the agriculture productivity of Pakistan.

- To analyze that how much climate change affects agriculture sector of Pakistan and prepare solid policy to get rid of climate change problem.

\section{Significance of the study:}

Study is important for following reasons:

- It will examine the economic effects of climate change on agriculture economy of Pakistan with a different approach.
- It will also show the problems arise due to this phenomenon and will explain in detail the suggestions to get rid of this situation.

- This study shows the clear picture of agriculture economic growth and climate in Pakistan.

- $\quad$ This study will assist the government and its officials to make policies and motivation for upcoming researchers.

\section{LITERATURE REVIEW}

Joshi et al. (2013) attempted to explore the impact of climate parameter on the cotton yields of the three districts in Marathwada, India. The objective of the study was to explore the climate parameters impact on the cotton yields of Maharashtra district. The time series data is used of the rainfall, maximum and minimum temperature relatively humidity minimum and maximum from 22 to 53 Metrological weeks. Data of the three districts for the period of 1977 to 2007 were obtained by India meteorological department, Pune obtained on CD disk. While the secondary data of area production and yield of Aurangabad, Beed and Jalna were obtained from Epitome of agricultural part I and part II. Multiple Regression Analysis, Correlation and coefficient of determination, ttest and Percentage of contribution were used as statistical techniques. It was found that the investigation of crops is totally depends on the rainfall pursued by temperature maximum and the relative moisture minimum. Result shows that the area and production both has increased in all three districts but the inconsistence of lesser yield remains same over the years.

Mohsin et al. 2011, tried to explore the impact of the climate change on agriculture, empirical evidence from the arid region. Objective of the study was to investigate the climate change impact on the agriculture of arid region. Cross sectional data was collected through the structured questionnaires from the Rawalpindi division with the help of the time series data of climate change variables attained by meteorological station. The Ricardian method was utilized to check the connections amongst atmosphere and Net Homestead Income (NHI) over the parched area. Creation of wheat product was the center subject of the study. Result demonstrates that the expansion in temperature has huge negative effect on the farming generation in bone-dry district. An expansion in income was envisioned with the ascent in precipitation. General level of negative compel of temperature is higher than positive result of the precipitation in locale. It was uncovered that $1 \%$ expansion in the temperature would prompt to loss of Rs. 4180 to the net income per annum.

Fields at el. 2016, endeavored to examine the worldwide scale environmental change, trim yields affiliation deliver with late day's warming. Changes in the worldwide generation of real yields are imperative drivers of sustenance costs; nourishment security and land utilize choices. Normal worldwide yields for these products are 
controlled by the execution of harvests in a huge number of fields disseminated over a scope of administration, soil and atmosphere administrations. In spite of the multifaceted nature of worldwide sustenance supply, here we demonstrate that straightforward measures of developing season temperatures and precipitation spatial midpoints in view of the areas of every harvest clarify at least $30 \%$ of year to year varieties in worldwide normal yields for the world's six most broadly developed products. For wheat, maize and grain, there is an obviously negative reaction of worldwide respects expanded temperatures. In view of these sensitivities and watched atmosphere patterns, we assess that warming since 1981 has brought about yearly joined misfortunes of these three products speaking to approximately $40 \mathrm{Mt}$ or $\$ 5$ billion every year, starting 2002. While these effects are little with respect to the mechanical yield increases over a similar period, the outcomes show as of now happening negative effects of atmosphere patterns on harvest yields at the worldwide scale.

Nairobi et al. (2006), tried to investigate the economic impact of climate change on the Kenyan agriculture. Objective of the study was to measure the climate change impact on the crops of agriculture in the Kenya. Cross sectional data was used on climate, soil hydrological data and the household data for a sample of 816 households. Seasonal Ricardian model was used to assess the impact of climate on net crop revenue per acre. It was found that climate affects the productivity of crops. There is a nonlinear relation between revenue and temperature and on one hand and between precipitation and revenue on the other. The results also present that the temperature section of the global warming is very important than rainfall. It was suggested that checking of the climate change and propagation of information to farmers to motivate adaptations to climate change.

Cline (2007) utilized the Ricardian factual and harvest model to build up an arrangement of accord agriculture effect gauges through the 2080s for more than 100 nations. He initially grew geologically itemized protrusions for alterations in precipitation and temperature in light of a benchmark emanation projection from the IPCC's Outflow Situations. Next, these climatic transform protuberances were connected to the agriculture effect models to evaluate the impacts of environmental change on rural efficiency. The last agreement appraisals were the weighted normal of the Ricardian gauges and the harvests demonstrate gauges.

The Ricardian time series method investigates the association ship between agriculture limit (measured via arrive esteem) and atmosphere factors (generally precipitation and temperature) on the premise of factual appraisals from farm review or nation level information. This approach naturally consolidates productive environmental change adjustments by farmers. The real reactions of the Ricardian approach are its obliviousness of value changes and that it neglects to completely control for the effect of different factors that influence cultivate livelihoods.

Karanja, M. 2006, endeavored to quantify the monetary effect of atmosphere on yields in Kenya. He utilizes cross sectional information on atmosphere, hydrological, soil information and family unit level information for a specimen of 816 families. For gauge the occasional Ricardian show for surveying the effect of atmosphere on net yield income per section of land. The outcomes demonstrate that atmosphere influences edit profitability. There is a non-straight relationship amongst temperature and income on one hand and amongst precipitation and income on the other. Evaluated negligible effects recommend that an unnatural weather change is hurtful for yield efficiency. Forecasts from worldwide course models affirm that an unnatural weather change will substantially affect net product income in Kenya. The outcomes additionally demonstrate that the temperature part of a dangerous atmospheric devotion is a great deal more critical than precipitation. Discoveries call for observing of environmental change and spread of data to farmers to urge adjustments to environmental change. Enhanced administration and protection of accessible water assets, water gathering and reusing of waste water could produce water for water system purposes particularly in the dry and semi bone dry zones.

Shakoor, et, al watched the general degree of negative effect of temperature is more prominent than the constructive outcome of precipitation in the locale. S. Edges et, Al. considered rainfed agribusiness underpins 40 percent of the Indian populace and contributes 44 percent to the national nourishment wicker container. David et al indicate essential of precipitation, which must be in adequate amount, additionally at a period and at a pace sufficient to the vegetative cycle of the plant. Kanga et, al, (2004), the amount of the stormy season is to be sure dictated by a few parameters, it span, which relies on upon the onset and suspension dates of the rainstorm, its circulation and its inconstancy. Al Bergel et, al. (1985), factual investigation demonstrates a positive connection amongst precipitation and the variety of cotton generation in Burkina faro. They discovered critical positive coefficients off relationship of 0.72 for the entire cotton zone and 0.67 for most escalated range of generation. Bella Medjo et al. [2005] as far as yield examination, precipitation in the north of Cameroon uncovered a positive and critical connection coefficient of 0.59 , in the nation has yearly precipitation beneath $600 \mathrm{~mm} /$ annum and south zone where precipitation surpasses $600 \mathrm{~mm}$ for every annum demonstrates no huge results. 


\section{Research Methodology}

Table 1: Selected variables

\begin{tabular}{|c|c|c|}
\hline Variables & $\begin{array}{l}\text { Description of the } \\
\text { variables }\end{array}$ & Source \\
\hline \multicolumn{3}{|l|}{ Dependent variable } \\
\hline AVAG & $\begin{array}{l}\text { Agriculture value added } \\
\text { annual growth rate }\end{array}$ & $\begin{array}{l}\text { Cresser \& } \\
\text { Aydinalp } 2008\end{array}$ \\
\hline \multicolumn{3}{|l|}{$\begin{array}{l}\text { Explanatory } \\
\text { variables }\end{array}$} \\
\hline $\mathrm{CO} 2 \mathrm{E}$ & Carbon oxide emission & $\begin{array}{l}\text { Cresser \& } \\
\text { Aydinalp } 2008\end{array}$ \\
\hline GGE & $\begin{array}{l}\text { Greenhouse gas } \\
\text { emission }\end{array}$ & $\begin{array}{l}\text { Cresser \& } \\
\text { Aydinalp } 2008\end{array}$ \\
\hline AME & $\begin{array}{l}\text { Agriculture methane } \\
\text { emission }\end{array}$ & $\begin{array}{l}\text { Cresser \& } \\
\text { Aydinalp } 2008\end{array}$ \\
\hline ANE & $\begin{array}{l}\text { Agriculture nitrous } \\
\text { oxide emission }\end{array}$ & $\begin{array}{l}\text { Cresser \& } \\
\text { Aydinalp } 2008\end{array}$ \\
\hline PD & Population density & Passel 2012 \\
\hline
\end{tabular}

Study analysis is based on the impact of climate change on the agriculture productivity of Pakistan for the period of 1974 to 2013. Agriculture value added annual growth rate is the dependent variable, and the explanatory variables are as follows $\mathrm{CO} 2$ is the carbon oxide emission, greenhouse gas emission, agriculture methane emission, agriculture nitrous oxide emission and population density. A time series data of all economic variables is taken from the World Bank Metadata of Pakistan, Handbook Statistics of Pakistan.

\section{Model specification}

To check the Order of integration or stationary of data we used the Augmented Dickey Fuller. The extra lag length of dependent variable is included in ADF test to check the problem of autocorrelation in model. Autoregressive distributed lag model should be acceptable on the strength of the Augmented dickey fuller test as if all the selected determinants are integrated at dissimilar order like 1(0) and 1(1), is the basic requirement to use the autoregressive distributed lag model. Otherwise if all selected variables are integrated at $1(0)$ order then a simple OLS method is used, while, if order of integration is at 1(1) Johanson cointegration test is used.

To see the impact of agriculture productivity on economic growth the estimated equation is as follows

$A V A G=\beta 0+\beta_{1} \mathrm{CO}_{2} \mathrm{E}+\beta_{2} \mathrm{GGE}+\beta_{3} \mathrm{AME}+\beta_{4} \mathrm{ANE}+\beta_{5}$ $\mathrm{PD}+\varepsilon_{i}$

Whereas,

$\varepsilon_{\mathrm{i}}$ is the Residual term, $\beta 0$ is the intercept term B1, $\beta 2, \beta 3$, $\beta 4, \beta 5, \beta 6, \beta 7$ are the slope coefficient.

The estimated equation to see the impact of climate change on the agriculture productivity of Pakistan through agriculture value added annual growth rate is taken as dependent variable is as follows

$A V A G=\beta 0+\beta_{1} \mathrm{CO}_{2} \mathrm{E}+\beta_{2} \mathrm{GGE}+\beta_{3} \mathrm{AME}+\beta_{4} \mathrm{ANE}+\beta_{5}$ $\mathrm{PD}+\varepsilon i$
Whereas, $\varepsilon_{\mathrm{i}}$ is the Residual term and $\beta$ o is the intercept term, while $B 1, \beta 2, \beta 3, \beta 4, \beta 5, \beta 6, \beta 7$ are the slope coefficient

Whereas, unrestricted vector error model in presented as below.

General ARDL equation;

$\Delta(A V A G)_{t}=\gamma_{0}+\sum_{i=1}^{a} \gamma 1(A V A G)_{t-i}+\sum_{i=0}^{b} \gamma 2(\mathrm{CO} 2 \mathrm{E})_{t-}$

$i+\sum_{i=0}^{c} \gamma 3(\mathrm{GGE})_{t-}$

${ }_{i}+\sum_{i=0}^{d} \gamma 4$ (AME) $t_{t-i}+\sum_{i=0}^{e} \gamma 5$ (ANE) $t_{t-i}+\sum_{i=0}^{e} \gamma 6(\mathrm{PD}){ }_{t-}$

${ }_{1}+\gamma_{7}(\text { AVAG })_{t-1}+\gamma 8(\text { CO2E })_{t-1}+\gamma 9(\mathrm{GGE})_{t-1}+\gamma_{10}(\mathrm{AME})_{\mathrm{t}-1}+\gamma_{11}(\mathrm{ANE})_{\mathrm{t}-}$

$1+\gamma_{12}(\mathrm{PD}) \mathrm{t}-1$. .

Equation 1 is the Auto regressive distributed lag model equation which presents the long run and short run relationship between explained and explanatory variable. $\gamma_{0}$ is the intercept term and short run coefficient of the determinants are as follows $\gamma 1, \gamma 2, \gamma 3, \gamma 4, \gamma 5, \gamma 6$ and the long run coefficients in auto regressive distributed lag model of the variables are as follows $\gamma 7, \gamma 8, \gamma 9, \gamma 10, \gamma 11, \gamma 12$ whereas, $\varepsilon_{I}$ is the disturbance term.

\section{Wald test (F- statistics)}

The wald test is used to set up the long run association between explained and explanatory determinants.

\section{Null Hypothesis}

$\mathbf{H}_{0}=, \gamma 8, \gamma 9, \gamma 10, y 11, y 12,=0$

(As no long run relationship exists)

\section{Alternative Hypothesis}

$\mathbf{H}_{1}=\gamma 7, \gamma 8, \gamma 9, \gamma 10, y 11, y 12 \neq 0$

(A long run relationship exists)

If the tabulated value is less than the F-statistics value then the alternative is accepted and null hypothesis is rejected, whereas if the tabulated value is greater than the Fstatistics value than the alternative is rejected and null is accepted.

\section{Long Run Relationship}

The longer period relationship between explained and explanatory variable is presented in the following equation.

$(A V A G)_{t-i}=\alpha+\sum_{i=1}^{z 1} \alpha 1 i(A V A G)_{t-i}+\sum_{i=0}^{z 2} \alpha 2 i(\mathrm{CO} 2 \mathrm{E})_{t}$

${ }_{I}+\sum_{i=0}^{z 3} \alpha 3(\mathrm{GGE})_{t-i}+\sum_{i=0}^{z 4} \alpha 4(\mathrm{AME})_{t-i}+\sum_{i=0}^{z 5} \alpha 5(\mathrm{ANE})_{t-}$

$i+\sum_{i=0}^{z 6} \alpha 6(\mathrm{PD})_{t-i}+\varepsilon_{i} \ldots$. (2)

\section{Short run relationship}

The short run relationship between explained and explanatory determinants is presented by the equation $3^{\text {rd }}$. the error correction term lagged as (ECM)t-1 is added in the equation to regulate the consequences.

$\Delta(A V A G)_{t}=\gamma_{0}+\sum_{i=1}^{k 1} \gamma 1 i(A V A G)_{t-i}+\sum_{i=0}^{k 2} \gamma 2 i(\mathrm{CO} 2 \mathrm{E})_{t-}$

$i+\sum_{i=0}^{k 3} \gamma 3 i(\mathrm{GGE})_{t-i}+\sum_{i=0}^{k 4} \gamma 4 i(\mathrm{AME})_{t-i}+\sum_{i=0}^{k 5} \gamma 5 i(\mathrm{ANE})_{t}$

$i+\sum_{i=0}^{k 6} \gamma 6 i(\mathrm{PD})_{t-i}+\lambda(E C M)_{t-i}+\varepsilon_{I} \ldots \ldots$ (3) 
(ECMt-i) error correction model presents the shorter period effect on the $X$ and $Y$ variable, longer period effect on the $X$ and $Y$ variable and speed of adjustment.

$\Delta \mathrm{P}_{t}=\gamma+\delta \Delta_{\mathrm{t}-1}+\lambda\left(\mathrm{ECM}_{\mathrm{t}-1}\right)+\varepsilon_{I} \ldots$.

ECM $\mathrm{t}_{\mathrm{t}-\mathrm{i}}$ error correction term is shown by equation 4 , in this equation $\delta$ shows the shorter period effect and $\lambda$ shows speed of modification. Disequilibrium value is shown by the error correction term.

\section{DATA ANALYSIS}

In mean estimation mean, standard deviation, skewness, and probability values of variables are presented. Table 2 is the general statistical description of the variables. Kurtosis and probability values are important in the analysis. The value of Kurtosis shows that the variable is platy kurtic or leptokurtic. Agriculture value added annual growth rate and agriculture nitrous oxide emission has a high peaked or leptokurtic distribution, while carbon oxide emission, greenhouse gas emission, agriculture methane emission and population density is platy kurtic. Jarque- Bera test of normality shows the combined results of kurtosis and skewness. JB test of normality shows that the ' $\mathrm{p}$ ' computed value of all variables is higher in ratio so all the variables are normally distributed.

Table 2: Mean estimation

\begin{tabular}{|c|c|c|c|c|c|c|}
\hline Variables & mean & St. dev. & Skewness & Kurtosis & J.B. & Prob. \\
\hline AVAG & 3.554803 & 3.525335 & -0.267377 & 3.872922 & 1.746591 & 0.417573 \\
\hline CO2E & 86033.54 & 48736.52 & 0.310453 & 1.774834 & 3.144260 & 0.207603 \\
\hline GGE & 213052.8 & 87939.36 & 0.418402 & 1.894369 & 3.204438 & 0.201449 \\
\hline AME & 69.53240 & 5.491149 & 0.251463 & 1.749928 & 3.026025 & 0.220246 \\
\hline ANE & 72.81305 & 4.381496 & -0.583348 & 2.564876 & 2.578990 & 0.275410 \\
\hline PD & 154.5211 & 45.74247 & 0.099833 & 1.787039 & 2.518570 & 0.283857 \\
\hline
\end{tabular}

Source: Author's calculations

\section{Augmented Dickey Fuller Test}

Null Hypothesis: Data has a unit root or variables are not stationary

Alt Hypothesis: Data has not unit root or variables are stationary

Table 3 is representing augmented dickey fuller test for the stationary of the variables

\begin{tabular}{|c|c|c|c|c|c|c|c|}
\hline Variables & \multicolumn{2}{|c|}{ At level } & \multicolumn{2}{|c|}{ At 1st Difference } & \multicolumn{3}{|c|}{ At 2nd Difference } \\
\hline & $\begin{array}{l}\text { Inter } \\
\text { cept }\end{array}$ & $\begin{array}{c}\text { Intr. \& } \\
\text { trend }\end{array}$ & Intercept & $\begin{array}{c}\text { Intr. \& } \\
\text { trend }\end{array}$ & $\begin{array}{l}\text { Inter } \\
\text { cept }\end{array}$ & $\begin{array}{l}\text { Intr. \& } \\
\text { trend }\end{array}$ & $\begin{array}{c}\text { Integra } \\
\text { tion }\end{array}$ \\
\hline AVAG & -7.811927 & & - & - & - & - & $\mathrm{I}(0)$ \\
\hline $\mathrm{CO} 2 \mathrm{E}$ & - & - & -5.475080 & - & - & - & $\mathrm{I}(1)$ \\
\hline GGE & - & - & -4.775897 & - & - & - & $\mathrm{I}(1)$ \\
\hline AME & - & - & -5.300221 & - & - & - & $\mathrm{I}(1)$ \\
\hline ANE & - & - & -7.820615 & - & - & - & $\mathrm{I}(1)$ \\
\hline PD & - & - & -5.49420 & - & - & - & $\mathrm{I}(1)$ \\
\hline
\end{tabular}

Source: Author's calculations

The Augmented dickey fuller test is used to check the stationary of the dataset either it has a unit root or not. Probability value of the dickey fuller test checks the further statistical test to be applied on the variables. In our hypothesis analysis null hypothesis is that dataset has not stationary, while according to alternative hypothesis the dataset is stationary. To check the stationary we apply the augmented dickey fuller test results are presented in the table 3. Mix trend of co integration is observed as dependent variables are integrated at level as agriculture value added annual growth rate, explanatory variables have co integration at first difference.

Table: 4 Bound Test for Co-integration

\begin{tabular}{|c|c|c|c|}
\hline Equation & $\begin{array}{c}\text { F-Statistics } \\
\text { Calculated }\end{array}$ & $\begin{array}{c}\text { Lower Bound } \\
\text { Critical Value }\end{array}$ & Conclusion \\
\hline $\begin{array}{c}\text { Equation (1) } \\
\text { AVAG / CO2E, GGE, }\end{array}$ & $\begin{array}{c}2.39 \\
\text { [0.0118] }\end{array}$ & $\begin{array}{c}2.26 \\
(90 \%)\end{array}$ & $\begin{array}{c}\text { Co- } \\
\text { integration } \\
\text { exist }\end{array}$ \\
\hline
\end{tabular}

Source: authors' calculation, computed F-statistics is 2.39 (significance at $1 \%$ level of marginal values). Critical values is as $\mathrm{k}=6-1=5$ is cited from the pesran et al (2001), case 111: unrestricted intercept and no trend. The numbers in parenthesis is shows the probabilities of F-statistics. Bound test shows that all the variables have long run association.

Table 4 is presenting the results of bound test. In the auto regressive distributed lag model $\mathrm{f}$ statistics calculated vale of the bound test is important, if the f statistics calculated value is greater than the lower bound critical value which is measured by the bound testing table then we can further measure the short run and long run analysis of the auto regressive model.

Table 5: Long Run Model

\begin{tabular}{|c|c|c|c|c|}
\hline \multicolumn{3}{|c|}{ Dependent Variable: AVAG } & & \\
\hline \multicolumn{3}{|c|}{ Method: Least Squares } & & \\
\hline \multicolumn{3}{|c|}{ Sample: 1974 2013 } & & \\
\hline \multicolumn{3}{|c|}{ Included observations: 40} & & \\
\hline Variable & Coefficient & Std. Error & t-Statistic & Prob. \\
\hline C & -0.154888 & 0.049180 & -3.149395 & 0.0033 \\
\hline CO2E & -0.071014 & 0.002299 & -0.352319 & 0.0267 \\
\hline GGE & 0.370054 & 0.024576 & -1.914631 & 0.0635 \\
\hline AME & 0.387001 & 0.015977 & 24.22275 & 0.7541 \\
\hline ANE & -0.021020 & 0.001390 & 1.452984 & 0.0549 \\
\hline PD & -0.027180 & 0.001454 & -0.259894 & 0.0964 \\
\hline
\end{tabular}

Table 5 is presenting the long run relationships among variables. Probability value shows the statistical significance of the all explanatory variables. To analyze the relationship between climate change and its impact on the agriculture productivity in Pakistan Auto regressive distributed lag model has been used. In the long run period the relation between variables is discussed as, the value of coefficient shows one unit increases in carbon oxide emission will cause 0.071-unit decrease in agriculture productivity in Pakistan. At the same time, one unit increase in greenhouse gas emission will cause to a 0.37 unit increase in agriculture value added annual growth in Pakistan. The probability value of greenhouse gas emission is 6.35 which shows it is statistical significant at $10 \%$ level of significance. The value of coefficient shows the one unit 
increases in the agriculture methane emission will cause to it 0.38 unit increase in agriculture value added growth in Pakistan. Probability value of agriculture methane emission is 75.41 which to higher than $5 \%$ or $10 \%$ level of significance so, the agriculture methane emission in not statistical significance. The value of coefficient shows oneunit increase in agriculture nitrous oxide due to a $-0.021-$ unit decrease in agriculture value added in Pakistan. Probability value 0.054 shows that the variable is significant at $10 \%$ level of significance. The value of coefficient shows the one-unit increase population density due to a -0.0271-unit decrease in agriculture value added annual growth in Pakistan. The performance of variables shows that there exist the long run relationships between the climate change and agriculture value added annual growth rate in Pakistan.

Table 6: Short Run Model

\begin{tabular}{|c|c|c|c|c|}
\hline \multicolumn{3}{|c|}{ Dependent Variable: D(AVAG) } & & \\
\hline \multicolumn{3}{|c|}{ Method: Least Squares } & & \\
\hline \multicolumn{3}{|c|}{ Sample (adjusted): 1973 2012S } & & \\
\hline \multicolumn{3}{|c|}{$\begin{array}{l}\text { Included observations: } \\
40 \text { after adjustments }\end{array}$} & & \\
\hline Variable & Coefficient & Std. Error & t-Statistic & Prob. \\
\hline $\mathrm{C}$ & 0.010713 & 0.003953 & 2.710049 & 0.0118 \\
\hline D(AVAG(-2)) & 244354 & 0.161099 & 1.516787 & 0.1414 \\
\hline $\mathrm{D}(\mathrm{CO} 2 \mathrm{E})$ & -0.00 & 0.000674 & -0.338566 & 0.0377 \\
\hline $\mathrm{D}(\mathrm{CO} 2 \mathrm{E}(-2))$ & 0.001174 & 0.000630 & 1.848633 & 0.0718 \\
\hline D(GGE) & -0.023247 & 0.016115 & -1.448149 & 0.0595 \\
\hline $\mathrm{D}(\mathrm{GGE}(-2))$ & 0.000578 & 0.016281 & 0.042174 & 0.0862 \\
\hline $\mathrm{D}(\mathrm{AME})$ & 0.063558 & 0.028951 & 2.195361 & 0.0373 \\
\hline $\mathrm{D}(\mathrm{AME}(-2))$ & -0.030368 & 0.039500 & -0.768813 & 0.4489 \\
\hline $\mathrm{D}$ (ANE) & 0.001146 & 0.000546 & 2.099993 & 0.0456 \\
\hline $\mathrm{D}(\mathrm{ANE}(-2))$ & 0.000986 & 0.000604 & 1.632373 & 0.0047 \\
\hline $\mathrm{D}(\mathrm{PD})$ & 0.002303 & 0.001057 & 2.179133 & 0.0386 \\
\hline $\mathrm{D}(\mathrm{PD}(-2))$ & 0.000955 & 0.000786 & 1.215683 & 0.2350 \\
\hline ECT(-1) & -0.238412 & 0.102692 & -2.321615 & 0.0284 \\
\hline
\end{tabular}

In ARDL (auto regressive distributed lag) model vector error correction model used to measure short run association of the variables. Short run period behavior among dependent and independent variable is shown in above table. Above table shows that the carbon oxide emission and greenhouse gas emission with $2^{\text {nd }}$ difference presents relationship with the agriculture value added annual growth at $10 \%$ probability value in the short period of time. The value of agriculture methane emission shows that there is no relationship between agriculture methane emission and agriculture value added annual growth in short period of time. Values of agriculture nitrous oxide emission describes that short run relationship exists between ANE and agriculture value added annual growth. In the shorter period of time the value of population density shows that it has no relationship with dependent variables. ECT (-1) representing the adjustment term value which is -0.2384 in short run period.
Table 7: Results of Regression Analyses

\begin{tabular}{|c|c|c|c|}
\hline R-squared & 0.881544 & Mean dependent var & 0.016220 \\
\hline Adjusted R-squared & 0.243231 & S.D. dependent var & 0.023062 \\
\hline S.E. of regression & 0.020074 & Akaike info criterion & -4.717596 \\
\hline Sum squared resid & 91.01047 & Schwarz criterion & -4.163076 \\
\hline Log likelihood & 104.9931 & Hannan-Quinn criter. & -4.518639 \\
\hline F-statistic & 2.012818 & Durbin-Watson stat & 1.917896 \\
\hline Prob(F-statistic) & 0.025895 & & \\
\hline
\end{tabular}

In regression analysis $r$-squared value .8815 shows that the dependent variable has $88 \%$ dependence on explanatory variables. The probability value of F- statistics is below the $5 \%(0.025 \%)$ which shows the overall significance of the model. D- Statistics value 1.917 which is near about 2 so we can conclude that there is no autocorrelation in our model.

Table 8: Diagnostic Tests

\begin{tabular}{|c|c|c|}
\hline Test Statistics & LM Version & F Version \\
\hline Serial Correlation & $\mathrm{CHSQ}(1)=.012536[.904]$ & $\mathrm{F}(1,26)=.010022[.921]$ \\
\hline Functional Form & $\mathrm{CHSQ}(1)=1.2336[.289]$ & $\mathrm{F}(1,26)=.79153[.382]$ \\
\hline Normality & $\mathrm{CHSQ}(2)=.18979[.905]$ & Not applicable \\
\hline Heteroscedasticity & $\mathrm{CHSQ}(1)=3.0105[.078]$ & $\mathrm{F}(1,36)=3.2095[.082]$ \\
\hline
\end{tabular}

Source: Author's calculation (Microsoft 4.1)

Diagnosting testing results shows that that there is no serial correlation among the variables and our variables are homoscedastic.

\section{Stability test}

CUSUM stability test in auto regressive distributed lags method (ARDL) is used to check the stability of the dataset. Selected variables and the dataset are stable because the cumulative sum of recursive residuals CUSUM graph is within the limits of $5 \%$ significance level and cumulative sum of square of recursive residuals CUSUMSQ graph is also within the limits of 5\% significant.

\section{CONCLUSIONS}

Change in climate with every passing day is one of the largest situations that the world is facing. Climate change has direct impact on the production of agriculture in all over the world. Pakistan is mainly an agricultural foundation based country and thus the economy of the country is directly with agriculture and agricultural Productive, earlier in Pakistan more than $70 \%$ agriculture depends upon the rainfall directly, as a result the temperature and rainfall always plays an important role in Pakistan agricultural system. Climate change have positive and significant impact on the agriculture productivity in different districts of the Punjab are found by (Rehana Siddiqui, Ghulam Samad, Muhammad Nasir) similarly (by Usman Shakoor, Abdul Saboor, 2011). Thus, Pakistan has one third of its total cropped area under Rainfall and other is with proper irrigated canal system in Pakistan. As a result, 65\% of agricultural in Pakistan is mostly relies upon the natural factors such, temperature, humidity, rainfall and so on. 
Auto regressive distributed lag model presents the existence of the short run and long run relationship between the dependent and explanatory variables. Long run period shows the relation between variables that carbon oxide emission, greenhouse gas emission, agriculture nitrous oxide and population density have a positive significant impact on the agriculture value added annual growth and agriculture methane emission in not statistical significance. In the Short run period behavior the dependent and independent variable shows that the ECT $(-1)$ is adjustment value which is -0.2384 . Carbon oxide emission and greenhouse gas emission with 2nd difference presents relationship with the agriculture value added annual growth at $10 \%$ probability value in the short period of time. The value of agriculture methane emission shows that there is no relationship between agriculture methane emission and agriculture value added annual growth in short period of time. Values of agriculture nitrous oxide emission describes that short run relationship exists between agriculture nitrous oxide and agriculture value added annual growth. In the shorter period of time the value of population density shows that it has no relationship with dependent variables. Long run and short run relationship among variables shows the positive and significant impact of the climate change on agriculture productivity in Pakistan. Global environment and temperature is changing with every passing day. Climate change can be also seen in the shape of floods, drought and other changes in the weather situation during last 5 years in Pakistan. Pakistan is agriculture base country so the global climate changes and its severe impact on the productivity of agriculture cannot be ignored.

\section{Policy ReCOMmENDATIONS}

On the basis of findings and conclusions we make the following recommendations: -

- It is concluded from the results that government can participate with its role by monitoring the climate change and its impact on the agriculture and then distribute the results of this monitoring with formers.

- Government should invent the new crop varieties according the need of warmed, heat and drought areas.

- Governments built such Policies that increase the farmer flexibility allow farmers to adjust according to need of new circumstances. Lastly, government should help to organize the irrigation and development projects in high temperature areas.

\section{REFERENCES}

ADB. (2009). "Building climate resilience in the agriculture sector in Asia and in the Pacific". Asian Development Bank, Annual Development Report, p. -9 .

Anderson, K., W. Martin, and D. van der Mensbrugghe. (2006). "Market and Welfare Implications of Doha Reform Scenarios. In Agricultural Trade Reform and The Doha Development Agenda", edited by W. Martin and K. Anderson. New York: Palgrave Macmillan and the World Bank.
Awan, A. (2012). Human Capital: Driving Force of Economic Growth in Selected Emergine Economies. Global Disclosure of Economics and Business, 1(1), 9-30. Retrieved from http://iproclaim.my/archive/index.php/gdeb/article/view/122

Awan, A. (2013). China's Economic Growth - 21st Century Puzzle. Global Disclosure of Economics and Business, 2(2), 76-96.

Awan, A. (2014). Brazil's Innovative Anti-Poverty \& Inequality Model. American Journal Of Trade And Policy, 1(2), 56 - 61.

Awan, A. (2015). Shifting Global Economic Paradigm. Asian Business Review, 4(3), 35-40. doi:http:/ /dx.doi.org/10.18034/abr.v4i3.264

Awan, A., \& Imran, M. (2015). Factors Affecting Food Price Inflation in Pakistan. ABC Journal of Advanced Research, 4(1), 75-90. Retrieved from http://iproclaim.my/archive/index.php/abcjar/article/view/201

Awan, A., \& Juiya, M. (2015). Role of Microfinance in Poverty Alleviation: Evidence from Pakistan. American Journal of Trade And Policy, 2(1), 37 - 44.

Awan, A., \& Khan, R. (2014). The Enigma of US Productivity Slowdown: A Theoretical Analysis. American Journal Of Trade And Policy, 1(1), 7 - 15.

Awan, A., Faridi, Z., \& Bibi, S. (2016). Correlates of Women's Labor Force Supply in Pakistan. Global Disclosure of Economics and Business, 5(1), 27-36. Retrieved from http://iproclaim.my/archive/index.php/gdeb/article/view/79

Awan, Abdul Ghafoor \& Rana Ejaz Ali Khan (2014) "The Enigma of US Productivity Slowdown: A Theoretical Analysis", American Journal of Trade and Policy. Vol.1 (1):7-15

Awan, Abdul Ghafoor (2013). Relationship between Environment and Sustainable Economic Development: A Theoretical approach to Environmental Problems", International Journal of Asian Social Sciences, Vol 3(3):741-761

Bruinsma, J.ed. (2003). World Agriculture: Towards 2015/2030: An FAO Perspective. UK: Earthscan.

Chaudhary, R. C., Nanda, J. S. and Tran, D.V. (2002), "Guidelines for Identification of Field Constraints to Rice Production", International Rice Commission, Food and Agriculture Organization of the United Nations, Room Climate Change on Agriculture: Empirical Evidence from Arid Region. Pak. J. Agri. Sci. 48(4), 327-333.

Darwin, R., M. Tsigas, J. Lewabdrowski, and A. Raneses. (1995). World Agriculture and Climate Change. Agricultural Economic Report no. 703 (June). Washington, DC: US Department of Agricultural, Economic Research Service.

Eid, H.M., S.M. El-Marsafawy and S.A. Ouda. 2007. Assessing the economic impacts of climate change on agriculture in Egypt: A Ricardian Approach. Development Research Group, Sustainable rural and urban development team: The World Bank, Policy Research Working Paper 4293.

Fischer G, Shah M, Tubiello F N and van Velhuizen H 2005 Socioeconomic and climate change impacts on agriculture: an integrated assessment, 1990-2080 Phil. Trans. R. Soc. B 360 2067-83.

Fleischer, A., I. Lichtman and R. Mendelsohn. 2008. Climate change, irrigation, and Israeli agriculture: Will warming be harmful? Ecol. Econ. 65:508-515.

Gbetibouo, G.A. and R.M. Hassan. 2004. Measuring the economic impact of climate change on major South African field crops. Global and Planetary Change 47:143-152. 
Hansen J, Ruedy R, Sato M and Lo K 2006 Global Temperature Trends: 2005 Summation (New York: NASA Goddard Institute for Space Studies)

IPCC (Intergovernmental Panel on Climate Change Working Group 2) 2001 Climate Change 2001: Impacts, Adaptation and Vulnerability IPCC Working Group 2.

IPCC. 2007. Climate Change 2007: The physical science basis. Contribution of Work Group I to the Fourth Assessment Report of the Intergovernmental Panel on Climate, Cambridge University Press, United Kingdom.

Kaiser, H.M., and T. Drennen. (1993). Agricultural dimensions of global climate change. St. Lucie, FL: St. Lucie Press.

Kurukulasuriya, P., and R. Mendelsohn.(2008). A Ricardian analysis of the impact of climate change on African cropland. AfJARE 2:1-23.

Lobell D B, Ortiz-Monasterio J I, Asner G P, Matson P A, Naylor R L and Falcon W P (2005) Analysis of wheat yield and climatic trends in Mexico Field Crops Res. 94 250-6.

Mendelsohn, R., A. Dinar and A. Sanghi. (2001). The effect of development on the climate sensitivity of agriculture. Environment and Development Economics 6:85-101.

Mendelsohn, R., W. Nordhaus and D. Shaw. (1994). The impact of global warming on agriculture: A Ricardian analysis. The American Economic Review 84:753-771.

Mitchell T D and Jones P D (2005). An improved method of constructing a database of monthly climate observations and associated high-resolution grids Int. J. Clim. 25 693-712.

MoE. (2009). Climate Change Vulnerabilities in Agriculture in Pakistan. Ministry of Environment, Government of Pakistan, Annual Report. pp.1-6.

Pakistan Economic Survey (2011-12), Chapter no. 2, Agriculture.
Reilly J (1999) What does climate change mean for agriculture in developing countries? A comment on Mendelsohn and Dinar The World Bank Res. Observer 14 295-305.

Rosenberg, N. J., ed. (1993). Towards and Integrated Assessment of Climate Change: The MINK Study. Dordrecht: Kluwer Academic Publisher.

Rosenzweig, C., and M. L. Parry. (1994). Potential Impact of Climate Change on World Food Supply. Nature 367:133-138.

Schlenker, W. and M. J. Roberts. (2006). Nonlinear Effects of Weather on Corn Yields. Review of Agricultural Economics, 28(3): 391-398.

Shakoor Usman, Abdul Saboor, Ikram Ali, and A.Q. Mohsin (2011). Impact of Climate Change on Agriculture: Empirical Evidence from Arid Region. Pak. J. Agri. Sci. 48(4), 327-333.

Stern. (2006). Stern review on the economics of climate change, H.M. Treasury.

Tubiello F N et al (2007) Crop response to elevated CO2 and world food supply: a comment on 'Food for Thought...' by Long et al, Science 312:1918-1921 Eur. J. Agron. 26 215-23.

USDA (1994) Major world crop areas and climatic profiles (revised) Agricultural Handbook No. 664 (Washington, DC: United States Department of Agriculture).

Van der Mensbrugghe, D. (2005). LINKAGE Technical Reference Document: Version 6.0. Mimeo. Washington, DC: The World Bank.

Yu, W., T. Hertel, P. Preckel, and J. Eales. (2004). Projecting World Food Demand Using Alternative Demand Systems. Economic Modelling 21: 99-129.

Zilberman, D., X. Liu, D. Roland-Holst, and D. Sunding. (2004). The Economics of Climate Change in Agriculture. Mitigation and Adaptation Strategies for Global Change 9: 365-382.

\section{SOCIAL SCIENCE RESEARCH NETWORK 2171 Monroe Avenue, Suite 203, Rochester, NY 14618, USA http://www.ssrn.com/en/}

AJTP Link: http://www.ssrn.com/link/American-Journal-Trade-Policy.html 